\title{
The Influence of Leadership in the Implementation of the Organizational Structure in the Aviation Industry: A Case Study of Kenya Civil Aviation Authority
}

\author{
Annah Maragia \& Dr. Sussy Wekesa \\ Department of Entrepreneurship, Procurement \& Management, Jomo Kenyatta University of \\ Agriculture \& Technology P.O. Box 62000- 00200 Nairobi, Annah Maragia P O Box 15464-00100 \\ Nairobi
}

\begin{abstract}
Organizational structure defines how tasks are divided, grouped, and coordinated in organizations. In the aviation industry, International Civil Aviation Organization (ICAO) recommends internationally accepted State organization structure in line with observance of the Chicago Convention in International Civil Aviation. Kenya Civil Aviation Authority (KCAA) is among the leading countries in Africa concerning implementation of the organizational structure. However it has achieved up to $62 \%$ of the expected $100 \%$; the purpose of this study aimed at establishing the influence of leadership in the implementation of organizational structure at KCAA. Contingency and ADKAR theories were used in this study and descriptive research design method was used. The targeted population comprised of 81 employees from five departments. Stratified random sampling was used with a sample size of 48 respondents. Questionnaires were the main data collection instrument. The data was generated using Statistical Package of Social Sciences (SPSS) version 23. The correlation of leadership showed a strong positive relationship in the implementation of the organizational structure. Findings indicated that most leaders are not committed, focused and do not involve employees in decision making. Based on findings, the following were the recommendations; Leaders ought to be committed, focused and embrace employee involvement in decision making.
\end{abstract}

Key Words: Organizational Structure, Management, Leadership Commitment, leadership Styles \&Skills

\section{INTRODUCTION}

Organizational structure is typically hierarchical arrangement of lines of authority, communications, rights and duties of an organization. It determines how the roles, power and responsibilities are assigned, controlled, and coordinated, and how information flows between the different levels of management (Rodrigues 2012). Organizational structure is the heart of an organizational change in any organization. No matter what kind of changes an organization may want to effect, the organizational structure will be required to support it for its successful implementation. It determines an organization's effective performance among other factors. It is therefore important to infer that for an organization to succeed in any change it intends to implement, it must ensure that the change is incorporated into its organizational structure. The structure of every organization must also dictate how many managers are required to direct their employees. This is known as the span of control and determines how many individuals a manager can efficiently and effectively manage. Companies with wider spans of control require fewer managers and are more efficient than companies with narrow spans of control, but if the span of control becomes too large, employees may not receive adequate leadership and support from their managers. Another element of organizational structure is centralization and decentralization, which determines where does decision-making authority lie. If top management makes all the organizational decisions with no input from lower-level personnel, the organization is considered to be centralized. The more that lowerlevel managers are involved in the decision-making process, the greater the degree of decentralization that exists in the organization. The final element of organizational structure is formalization, which determines to what degree the jobs in the organization are standardized. A highly formalized job has clearly defined procedures and leaves organizational members little freedom in regard to how they perform their tasks. A low degree of formalization, on the other hand, allows employees a high degree of flexibility in how they get their jobs done (Armstrong, 2006).

\subsection{Statement of the Problem}

In aviation industry, International Civil Aviation Organization (ICAO) recommends the international organizational structure in line with the observance of the Chicago Convention in International Civil Aviation. The aviation business depends heavily on the organizational structure for its safety and growth. The external 
forces such as economic and political instability in most African countries, have hindered the implementation level of recommended global organization structure. Statistics indicate that Kenya Civil Aviation Authority (KCAA) is ahead in most African countries and indeed the leading in East Africa in the implementation of the recommended organizational structure. This is largely attributed by its favorable external forces like stable political environment, good legal framework and availability of funds for the exercise (Munyi, 2010). However, it has only implemented up to $62 \%$ of the required organization structure (KCAA, 2014). According to Odhiambo (2011), KCAA had allocated funds to facilitate the restructuring process of up to the tune of Ksh.15 million which has not been fully utilized. (Kitao,2013) noted that KCAA had hired the service of the Directorate of Personnel Management (DPM) to do employees skills audit as one way of implementing the recommended organizational structure and the report was concluded and given to KCAA over a year ago but up to date, the report has neither been released nor implemented. He points out the failure of unreleased DPM restructuring report as a result of influence some internal forces such as poor leadership style with wrangles among the top management because of vested interest, and lack of team work among the leaders themselves and with other employees as well. Studies done on Kenya Civil Aviation Authority (KCAA) have not exhaustively tackled the internal forces and their influence in the implementation of the organizational structure (Munyi 2010; Odhiambo, 2011 \&Kitao, 2013). The aim of this study was to establish the influence of leadership in the implementation of the organizational structure at Kenya Civil Aviation Authority (KCAA). It focused on the influence of leadership commitment, skills and types of leadership on achieving the implementation of the organizational structure at KCAA.

\subsection{Research objectives}

The main objective of this study was to establish the influence of leadership in the implementation of organizational structure at Kenya Civil Aviation Authority (KCAA. The specific objective is to assess the extent to which leadership influence the implementation of the organizational structure at KCAA.

\section{Literature Review}

The two relevant theories to the study used were contingency theory highlights possible means of differentiating among alternative forms of organization structures and systems of management. The contingency approach implies that organization theory should not seek to suggest one best way to structure or manage organizations but should provide insights into the situational and contextual factors which influence management decisions. Organizational structure is a valuable tool in achieving coordination, as it specifies reporting relationships of who reports to whom, delineates formal communication channels, and describes how separate actions of individuals are linked together (Pace, 2004). Another theory is model-an acronym for Awareness, Desire, Knowledge, Ability and Reinforcement. The ADKAR model-an acronym for Awareness, Desire, Knowledge, Ability and Reinforcement was first published by Prosci in 1998 after research with more than 300 companies undergoing major change projects. In 2006, Prosci released the first complete text on the ADKAR model (Jeff ,2006). This model is probably one of the most well known, widely used and efficient models in the change management field (Harvey, 2009). This model is intended to be a coaching tool to help employees through the change process. The first step in managing any type of organizational change is to understand how leaders should manage change with a single individual. In essence, to make a change successful, an individual needs awareness of the value for change, desire to participate and support the change, knowledge on how to change, ability to implement required skills and behaviors and reinforcement to sustain the change. ADKAR describes successful change at the individual level. If this model is applied well and adopted, it can be of great importance in implementing organizational structure which involves a lot of alignment and changes from the norm.

\subsection{Conceptual Framework}

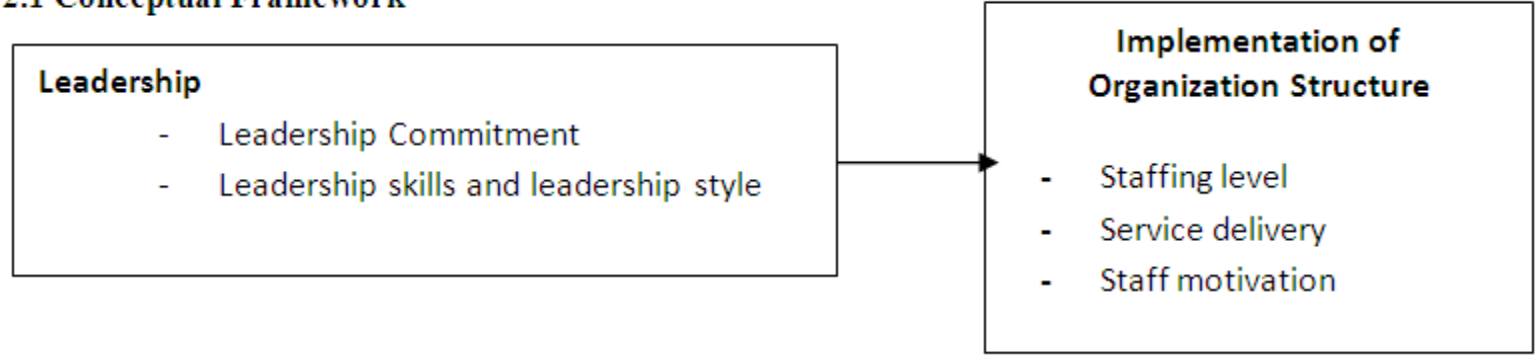

Dependent Variable Figure 1: Conceptual Framework 
Leadership is also defined as the act of providing directions, energizing others and obtaining their voluntary commitment to the leader's vision (Bloisi et al.,2007). For (Senge 2005), leadership is associated with stimulants and incentives that motivate people to reach common objectives. The essence of leadership is to achieve the intended objectives with and through people (Hersey et al., 2001).According to Koech \& Namusonge (2012), one of the most prominent formats for classifying and studying leadership includes; three styles-transformational, transactional and laissez-faire leadership. In this approach, leadership is conceptualized by the behavioral areas from laissez-faire style or non-leadership, through transactional leadership which hinges on reward system and punishments to transformational leadership which is based on inspiration and behavioral charisma (Bass \& Avolio, 2003). The approach is chosen because of its currency in management research and the efficiency demonstrated through research findings. The various components are now elaborated. Another Leadership style is Laissez - faire Style; where an avoidant leader may either not intervene in the work affairs of subordinates or may completely avoid responsibilities as a superior and is unlikely to put in effort to build a relationship with them. Laissez - faire style is associated with dissatisfaction, unproductiveness and ineffectiveness. It is the task of leaders to know which leadership style to apply

\section{RESEARCH METHODOLOGY}

A descriptive research method was used in the targeted population of 81 employees of KCAA based in headquarters. This method was appropriate for this study as it provides a quantitative description of attitudes, experience and opinions of the sample population. The study comprised the population size of 48 employees from five departments namely human recourse, Finance, Procurement, Air Navigation Services and Communication. Stratified simple random sampling was used to select individuals from the population to represent the characteristics found in the entire group. Data was collected using questionnaires with both open and closed questions. Pilot testing of $15 \%$ of the sample size was done. The independent variable was identified and measured using a five-point scale ranging from 1(strongly agree) to 5 (strongly disagree). The respondent's demographic information such as: age, gender, education level, departments and work experience were also captured. The internal consistency technique of validity was used where the internal consistency of data was determined from scores obtained from a single test administered by the researcher to a sample of subjects. The scores obtained in one item was correlated with scores obtained from other items in the instrument. Cronbach's Coefficient Alpha, was then computed to determine how items correlated among themselves. A multivariate regression model was applied to determine the relative importance of leadership in respect to its contribution to the implementation of the organizational structure in KCAA. A confidence level of $95 \%$ was used.

\section{RESEARCH FINDINGS}

The data was then analyzed using descriptive and inferential statistical measures as follows:

Table 1: Demographic profile of the sample $(n=42)$ Age Bracket

\begin{tabular}{|l|c|c|}
\hline Age Bracket & Frequency & Percentage \\
\hline Under 25 years & 4 & 10 \\
\hline 26 to 35 years & 10 & 24 \\
\hline 36 to 45 years & 17 & 40 \\
\hline Over 46 & 11 & 26 \\
\hline Total & 42 & 100 \\
\hline
\end{tabular}

\section{Gender}


Figure 2: Gender

Education Level

\begin{tabular}{|l|l|l|}
\hline Level of Education & Frequency & Percentage \\
\hline Secondary school & 2 & 5 \\
\hline Tertiary & 14 & 33 \\
\hline Degree & 17 & 40 \\
\hline Masters & 9 & 21 \\
\hline
\end{tabular}

Department Distribution

\begin{tabular}{|l|l|l|}
\hline Name of Department & Frequency & Percentage \\
\hline Human Resource & 14 & 33 \\
\hline Finance & 11 & 26 \\
\hline Procurement & 6 & 14 \\
\hline Air Navigation Services & 8 & 19 \\
\hline Corporate Communication & 3 & 7 \\
\hline Total & $\mathbf{4 2}$ & $\mathbf{1 0 0}$ \\
\hline
\end{tabular}

Work experience

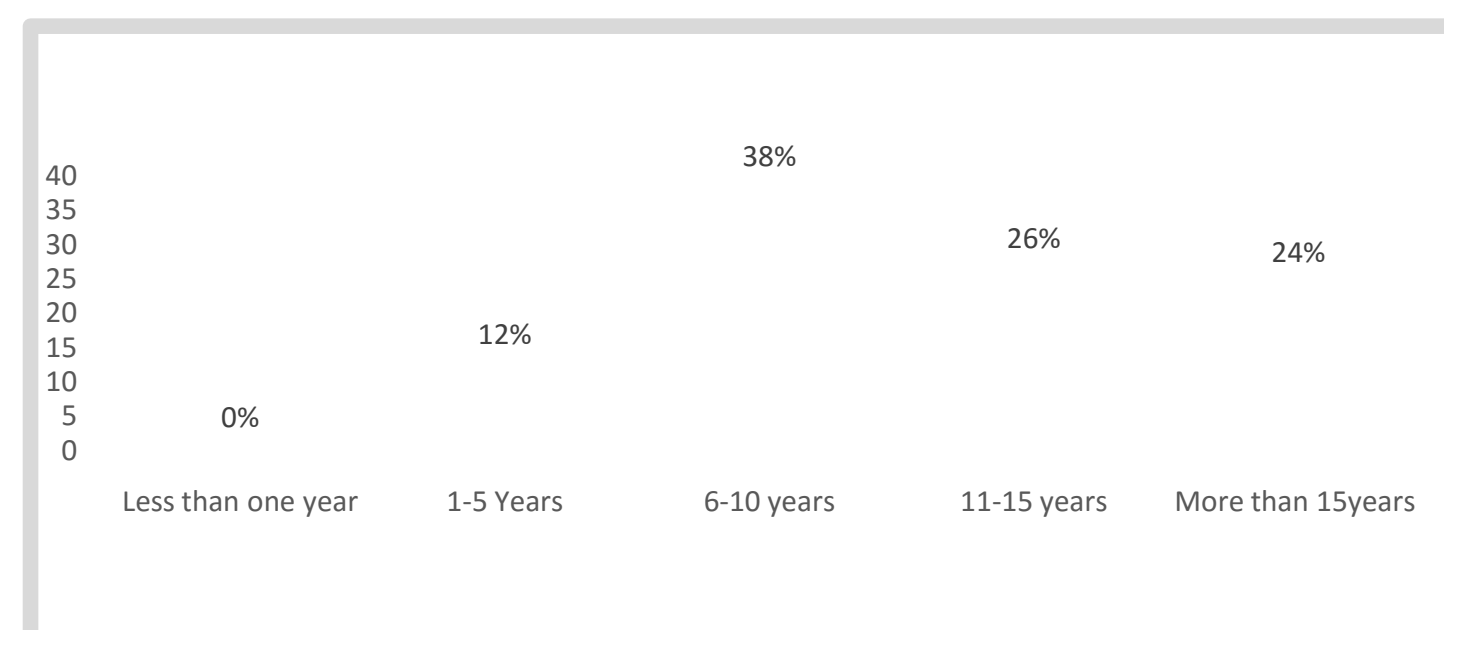

Figure 3: Work Experience. 


\subsection{Descriptive Statistics}

Table 2: Influence of Leadership on the Implementation of Organizational Structure

\begin{tabular}{|c|c|c|c|c|c|c|c|}
\hline \multirow[t]{2}{*}{ Statement } & \multicolumn{5}{|c|}{ Response (\%) } & \multirow[b]{2}{*}{$\begin{array}{c}\text { Mea } \\
\text { n }\end{array}$} & \multirow[b]{2}{*}{ Std.D } \\
\hline & $\begin{array}{l}\mathbf{S} \\
\mathbf{A}\end{array}$ & $\mathbf{A}$ & $\mathbf{N}$ & $\mathbf{D}$ & SD & & \\
\hline $\begin{array}{l}\text { KCAA leadership provide sufficient } \\
\text { corporate direction }\end{array}$ & 4.8 & $\begin{array}{c}28 . \\
6\end{array}$ & $\begin{array}{c}16 . \\
7\end{array}$ & 31 & 19 & 2.69 & 1.22 \\
\hline $\begin{array}{l}\text { Leaders in KCAA influence positively } \\
\text { the implementation of the } \\
\text { organizational structure }\end{array}$ & 4.8 & 9.5 & $\begin{array}{c}23 . \\
8\end{array}$ & $\begin{array}{c}38 . \\
1\end{array}$ & $\begin{array}{c}23 . \\
8\end{array}$ & 2.33 & $\begin{array}{c}1.09 \\
7\end{array}$ \\
\hline $\begin{array}{l}\text { Leaders in KCAA work in harmony } \\
\text { towards implementation of the } \\
\text { organizational structure }\end{array}$ & 4.8 & $\begin{array}{c}21 . \\
4\end{array}$ & $\begin{array}{c}28 . \\
4\end{array}$ & $\begin{array}{c}26 . \\
2\end{array}$ & 19 & 2.67 & $\begin{array}{c}1.16 \\
2\end{array}$ \\
\hline $\begin{array}{l}\text { Leaders involve employee fully on the } \\
\text { implementation of the organizational } \\
\text { structure }\end{array}$ & $\begin{array}{c}11 . \\
9\end{array}$ & $\begin{array}{c}23 . \\
8\end{array}$ & $\begin{array}{c}18 . \\
6\end{array}$ & $\begin{array}{c}21 . \\
4\end{array}$ & $\begin{array}{c}14 / \\
3\end{array}$ & 2.98 & $\begin{array}{c}1.23 \\
9\end{array}$ \\
\hline $\begin{array}{l}\text { KCAA Leadership is competent } \\
\text { enough to implement organizational } \\
\text { structure }\end{array}$ & 9.5 & 19 & $\begin{array}{c}33 . \\
3\end{array}$ & $\begin{array}{c}21 . \\
4\end{array}$ & $\begin{array}{c}16 . \\
7\end{array}$ & 2.83 & $\begin{array}{c}1.20 \\
8\end{array}$ \\
\hline $\begin{array}{l}\text { The right leadership style is applied } \\
\text { KCAA to ensure the implementation } \\
\text { of the organizational structure }\end{array}$ & 9.5 & $\begin{array}{c}16 . \\
7\end{array}$ & $\begin{array}{c}23 . \\
8\end{array}$ & $\begin{array}{c}26 . \\
2\end{array}$ & $\begin{array}{c}23 . \\
8\end{array}$ & 2.62 & $\begin{array}{c}1.28 \\
7\end{array}$ \\
\hline $\begin{array}{l}\text { Top management is committed to } \\
\text { the organizational structure } \\
\text { implementation and inspires and } \\
\text { motivates employees to support the } \\
\text { process }\end{array}$ & 9.5 & 19 & $\begin{array}{c}26 . \\
2\end{array}$ & $\begin{array}{c}23 . \\
8\end{array}$ & $\begin{array}{c}21 . \\
4\end{array}$ & 2.71 & $\begin{array}{c}1.27 \\
4\end{array}$ \\
\hline $\begin{array}{l}\text { Leaders have increased sense of trust } \\
\text { in the organization }\end{array}$ & 7.1 & $\begin{array}{c}23 . \\
8\end{array}$ & $\begin{array}{c}23 . \\
8\end{array}$ & $\begin{array}{c}14 . \\
3\end{array}$ & 31 & 2.62 & $\begin{array}{c}1.34 \\
3 \\
\end{array}$ \\
\hline$n=42$ & & & & & & & \\
\hline
\end{tabular}

\subsection{Correlation Analysis}

Correlation is a measure that indicates the extent to which two or more variables fluctuate together. The correlation technique is used to analyse the degree of relationship between two variables (Mugenda \& Muge nda, 2003). A positive correlation indicates the extent to which those variables increase or decrease in parallel; a negative correlation indicates the extent to which one variable increases as the other decreases. While correlation analysis is the use of statistical correlation to evaluate the strength of the relations between variables.

In investigating relationships, we are examining the strength of a connection between two characteristics belonging to the same individual or equipment. Correlation can be positively related that is an increase in one variable coincides with an increase in another variable. It can be also negative, that is as one increases the other reduces or zero/random correlation when one real relationship occurs. Coefficient of determination (R2) provides the amount of common variation between two variables or the amount of variation in dependent variable explained by variation in dependent variables when converted to percentage. Correlation analysis was done to calculate Karl Pearson and Spearman's Correlation Coefficients between implementation of organization structure. Significance values of less than 0.01 were considered sufficient for a relation to exist. The results are presented in table 4.21. A correlation coefficient is a statistical measure of the degree to which changes to the value of one variable predict change to the value of another. In positively correlated variables, the value increases or decreases in tandem. In negatively correlated variables, the value of one increases as the value of the other decreases. The correlation coefficients between the dependent and independent variables using Karl Pearson Coefficient and Spearman Coefficient and the results are shown in table 4 below.

Table 4: Correlation Coefficients

\begin{tabular}{|l|l|l|l|l|}
\hline $\begin{array}{l}\text { Independent } \\
\text { variable }\end{array}$ & $\begin{array}{l}\text { Karl Pearson } \\
\text { coefficient }\end{array}$ & $\begin{array}{l}\text { Significance } \\
(\mathbf{2} \text { - tailed })\end{array}$ & $\begin{array}{l}\text { Spearman Rank } \\
\text { Coefficient }\end{array}$ & $\begin{array}{l}\text { Significance } \\
(\mathbf{2} \text { - tailed })\end{array}$ \\
\hline Leadership & 0.825 & 0.000 & 0.8293 & 0.000 \\
\hline
\end{tabular}


The coefficient of correlation of 0.825 (Karl Pearson) and 0.829 (Spearman) shows a strong positive relationship between leadership commitment and the implementation of the organizational structure.

The two detailed significance values of the correlation analysis for both Karl Pearson and Spearmans' rank were below the set significance level of 0.05 corresponding to $95 \%$ confidence level. Leadership commitment recorded the highest significance with the significance value of 0.000 A related trend was realised with Spearman correlation analysis where leadership commitment was more significant of 0.001 .

\subsection{Regression Analysis}

4.3.1 Leadership and implementation of the organizational structure Table 5: KCAA leadership in relation to staffing level

\begin{tabular}{|l|l|l|l|l|l|}
\hline Model & R & R Square & $\begin{array}{l}\text { Adjusted } \\
\text { Square }\end{array}$ & $\begin{array}{l}\text { Std. Error of the } \\
\text { Estimate }\end{array}$ \\
\hline 1 & $\begin{array}{l}.252 \\
\mathrm{a}\end{array}$ & .064 & .045 & .651 \\
\hline \multicolumn{5}{|l|}{ a. Predictors: (Constant), Leadership commitment, Leadership skills and style } \\
\hline \multicolumn{7}{|l}{ b. Dependent Variable: Sufficient staffing level } \\
\hline
\end{tabular}

The regression analysis for leadership in relation to achieving sufficient staffing level showed a weak positive relationship between the two variables. The results were computed at $95 \%$ confidence level and are summarized and presented in table 5 above.

R Square value was found to be .064 implying that $6.4 \%$ variability in achieving sufficient staffing level in KCAA is explained by leadership commitment in KCAA. The bulk of variation $(93.6 \%)$ is explained by variation of other factors.

Table 6: KCAA leadership commitment in relation to service delivery

\begin{tabular}{|l|l|l|l|l|l|}
\hline Model & $\mathbf{R}$ & R Square & $\begin{array}{l}\text { Adjusted } \\
\text { Square }\end{array}$ & $\begin{array}{l}\text { Std. Error of the } \\
\text { Estimate }\end{array}$ \\
\hline 1 & $\begin{array}{l}.661 \\
\text { a }\end{array}$ & .437 & .401 & .113 \\
\hline \multicolumn{5}{|l|}{ a. Predictors: (Constant), Leadership commitment, Leadership skills and style } \\
\hline \multicolumn{4}{|l}{ b. Dependent Variable: Service delivery } \\
\hline
\end{tabular}

The regression analysis for leadership in relation to service delivery showed a moderate positive relationship between the leadership commitments and service delivery as shown in table 6.R. Square value was found to be 0.437 which implies that $43.7 \%$ variability of service delivery is attributed to leadership commitment in Kenya Civil Aviation Authority (KCAA). The other variation of $56.3 \%$ is explained by variation of other factors.

Table 7: KCAA leadership in relation to staff motivation

\begin{tabular}{|l|l|l|l|l|}
\hline Model & R & R Square & Adjusted R Square & $\begin{array}{l}\text { Std. Error of the } \\
\text { Estimate }\end{array}$ \\
\hline 1 & $\begin{array}{l}.642 \\
\text { a }\end{array}$ & .412 & .402 & .034 \\
\hline \multicolumn{6}{|l|}{ a. Predictors: (Constant), Leadership commitment, Leadership skills and style } \\
\hline
\end{tabular}

The regression analysis for leadership in relation to service delivery showed a moderate positive relationship between the leadership commitments in relation to staff motivation as shown in table 7 .

The coefficient of determination (R. Square) was found to be 0.412 . This means that $41.2 \%$ variability in staff motivation can be attributed to leadership commitment in Kenya Civil Aviation Authority (KCAA). The other variation of $59.8 \%$ is explained by variation of other factors.

The $\mathrm{R}$ value of 0.642 shows that there was a moderate positive relationship between leadership commitments and staff motivation. 
Table 11: Regression Coefficients

\begin{tabular}{|l|l|l|l|l|l|l|}
\hline \multicolumn{2}{|l|}{ Model } & \multicolumn{2}{|l|}{$\begin{array}{l}\text { Unstandardized } \\
\text { Coefficients }\end{array}$} & $\begin{array}{l}\text { Standardized } \\
\text { Coefficients }\end{array}$ & t & Sig. \\
\hline 1 & $\mathrm{~B}$ & $\begin{array}{l}\text { Std. } \\
\text { Error }\end{array}$ & Beta & & \\
\hline \multirow{2}{*}{1} & (Constant) & 3.504 & 1.780 & & 1.968 & .001 \\
\cline { 2 - 8 } & Leadership & .565 & .150 & .563 & 2.213 & .000 \\
\hline
\end{tabular}

The above regression analysis shows the results between implementation of organizational structure and independent variables which is leadership. According to Mugenda \& Mugenda (2003) regression analysis is a type of analysis used when a researcher is interested in finding out whether an independent variable predicts a given dependent variable. It has many practical uses including prediction of the effect of a particular independent variable against the dependent variable. Its analysis can be applied to quantify the strength of the relationship between $y$ and the $X_{i}$, to assess which $\mathrm{Xi}$ may have no relationship with $y$ at all, and to identify which subsections of the $\mathrm{X}_{i}$ contain redundant information about $\mathrm{y}$. A multivariate regression model was applied to determine the relative importance of each of the two variables with respect to their contribution to full implementation of the organizational structure in KCAA. A precision of 0.05 was used. The regression equation is:- $\mathrm{Y}=\boldsymbol{\beta}_{0}+\boldsymbol{\beta}_{1} \mathrm{X}_{1}+\varepsilon$

Where:-

$\mathrm{Y}$ - Implementation of organizational structure,

$\mathrm{X}_{1}$ - Leadership

$\boldsymbol{\beta}_{0}-$ Constant term

$\varepsilon$ - Error term

$\boldsymbol{\beta}_{1},-$ coefficients of independent variable

The regression model above indicates that leadership has the high contribution to the implementation of the organizational structure at Kenya Civil Aviation Authority (KCAA).

\section{4 Findings}

\subsubsection{Leadership and Organizational Structure}

According to the study findings, leadership has a great influence in the implementation of the organizational structure. At Kenya Civil Aviation Authority (KCAA) leaders have been considered as one of the greatest hindrances to implementing the organizational structure. Some leaders have been perceived incompetent who lack corporate direction, have negative influence, do not work in harmony, and do not involve employees in matters pertaining to the implementation of the organizational structure. Respondents also indicated that some leaders practise bad leadership style and they lack commitment towards the implementation of the new organization structure. Further the study established that most employees have no trust in the KCAA leadership and they perceive them as corrupt. This study agrees with the findings of Shipper Manz (2002) that empowering leaders use encouraging behaviours that build competence and confidence. Leading by example, participative decision making, coaching, informing and showing concern for and interacting with the members are all forms of empowering leadership. An individual and members of the teams should be empowered. By so doing, the organization will be able to achieve its objectives and this will make the organization in question to be competing with others in terms of human resource utilization and achieving the intended organizational goals.

The leader who does not have the ability to lead other people, manager who does not acquire the role of a leader, will never manage to bring subordinates and organizational needs together in order to promote efficient operations (Mintzberg, 2009). As per the analysis from the study, there is a need for the right combination of personality traits, appropriate skills, and style of leadership. Interestingly, these combination varies dependently on the position and level of management. Goals and visions are very important to any organization and senior managements together with all employees' ability to work on achieving them (Leavitt, 2005). From the findings, quality of leadership is a vital tool to implement the organizational structure since it is the manpower which will manage all other available machinery towards achieving organizational structure. Other leadership weakness respondents expressed include corruption, lack of focus and lack of team work in some of the leaders.

\section{CONCLUSION}

The findings revealed that the implementation of organizational structure at Kenya Civil Aviation Authority (KCAA) is not yet fully implemented as required by ICAO. The findings also revealed that leadership has a great influence in the implementation of the organizational structure. Further it was discovered that some 
leaders in KCAA are not committed and focused towards implementing the organizational structure. Other facts discovered on leaders include corruption and lack of team work.

\section{RECOMMENDATIONS}

The study recommends that KCAA leaders ought to change and be committed towards to the implementation of the organizational structure. Leadership skill and leadership style are essential traits in effective leadership. Leaders must put their personal interest aside, be committed and focused towards achieving the implementation of the organizational structure and lead by example. Further leaders need can work as a team and know how to handle employee well to gain back their support and trust towards implementing the organizational structure.

\section{REFERENCES}

[1] Rodrigues, C. C. (2012). Global Aviation Organizational Structure Concerns. An International Journal Vol.5 New York: McGraw Hill

[2] Armstrong M. (2006). A Handbook of Human Resource Management Practice, 10th Edition, Kogan Page Publishers, London and Philadelphia

[3] Munyi, I. K (2011). Influence of Organizational Factors in the adoption of Safety Standards at KCAA, Wilson

[4] Airport Nairobi.

[5] KCAA.(2013) Human Resource Manual. Nairobi: KCAA

[6] Odhiambo, E.(2011). External factors affecting the Organizational Structure Management: Case Study; Kenya Civil Aviation Authority

[7] Kitao A. (2013), Effects of organization Structure on Employee Performance; Case study; Kenya Civil Aviation Authority

[8] Pace, R.W. and Faules, D.F. (2004). Organizational Communication. $3^{\text {rd }}$ ed; New Jersey: Prentice Hall Englewood.

[9] Jeff P (2007). The Challenge of Organizational Change: How Companies Experience It and

[10] Leaders Guide It, Free Press, New York, NY.

[11] Hersey, P., Blanchard, K.H, and Johnson, D.E. (2007), Management of Organizational Behavior: Leading Human Resources, Prentice Hall Inc

[12] Bloisi, W., Cook, C.W., \& Hunsaker, P.L. (2007). Management \& organizational Behaviour. 2nd edition. Maidenhead: McGraw-Hill

[13] Senge, P. (2005). The Dance of Managing Change: The challenges of Sustaining Momentum in Learning

[14] Organization. London: Nicholas Brealey Publishing

[15] Harvey, C, \& Brown, R.(2001). An experiential Approach to Organizational Development $6^{\text {th }}$

[16] ed.).New Jersey: Prentice Hall Inc

[17] Koech P.M \&Namusonge,G.S. (2012). Effects of Leadership Styles on Organizational Performance at State

[18] Corporations in Kenya. Retrieved 14, 01, 2016 from www.ijbcnet.com

[19] Mugenda, M.O. and Mugenda, G.A. (2003). Research Methods: Quantitative and Qualitative Approaches. Acts Press

[20] Shipper, F. M. Manz, C.C, (2002) Shared Leadership: The Do's and Don'ts in Shared Entrepreneurship Enterprises, New York: Palgrave Macmillan.

[21] Mintzberg, H. (2009). Tracking Strategies: Toward a general theory of strategy formation. New York. Oxford University Press

[22] Harold J. Leavitt.(2005), Why Hierarchies Are Here to Stay and How to Manage Them More Effectively. John Wiley \& Sons, Inc 